doi: $10.26529 /$ cepsj.510

\title{
Change, Challenge, Transformation: A Qualitative Inquiry into Transformative Teacher Learning
}

Helena Kovacs ${ }^{1}$

$\approx$ In its essence, transformative learning is a dynamic and ever-emerging process, according to the core literature that deals with it. As such, when examined from the perspective of teacher professional development, transformative learning ceases being solely related to an individual and becomes a composition within which the individual creates and expands forms that need change. Thus, teacher learning that focuses only on new technology, methodology, and classroom management remains informative and valuable, but without a transformative character. This paper explores the underpinning principles of transformative learning by observing the notions of transformative change from the perspective of two non-traditional schools: one in Hungary and the other in Portugal. As such, the analysis and conclusions are formed using the data collected through a qualitative inquiry of teachers and principals from the two selected schools. The results suggest that teacher transformative learning in the two specific settings is intimately related to the awareness and need of change in education provisions, as well as with the challenges that this change brings. The gathered insights pave a way to a better understanding of the intricate and delicate tapestry of teacher learning in occasions in which it embraces an everlasting reflective and transformative character.

Keywords: transformative learning, educational change, teacher collaboration, school development 
Sprememba, izziv, transformacija:

kvalitativna raziskava transformativnega učenja učiteljev

Helena Kovacs

$\propto$ Transformativno učenje je v svojem bistvu glede na temeljno literaturo področja dinamičen proces. Kot takšno transformativno učenje, preučevano skozi perspektivo profesionalnega razvoja učiteljev, ni več povezano samo s posameznikom, ampak postane kompozicija, znotraj katere posameznik ustvarja in razširja oblike, ki terjajo spremembo. Učenje učiteljev, ki se tako usmerja samo na novo tehnologijo, metodologijo in na upravljanje razreda, sicer ostaja informativno in dragoceno, vendar brez transformativnega značaja. Ta prispevek raziskuje temeljna načela transformativnega učenja $\mathrm{z}$ opazovanjem pojmov transformativne spremembe $s$ perspektive dveh netradicionalnih šol: ene iz Madžarske, druge iz Portugalske. Analiza in sklepi so oblikovani $\mathrm{z}$ uporabo podatkov, pridobljenih $\mathrm{v}$ kvalitativni raziskavi učiteljev in ravnateljev obeh izbranih šol. Izsledki nakazujejo, da je transformativno učenje učiteljev v obeh kontekstih tesno povezano $\mathrm{z}$ zavedanjem in $\mathrm{s}$ potrebo po spremembi v načinih nudenja in zagotavljanja izobraževanja pa tudi z izzivi, ki jih takšna sprememba nosi. Zbrani vpogledi tlakujejo pot do boljšega razumevanja zapletene in občutljive tapiserije učenja učiteljev v situacijah, ki zaobjemajo njen neskončno reflektiven in transformativen značaj.

Ključne besede: transformativno učenje, edukacijske spremembe, sodelovanje učiteljev, razvoj šol 


\section{Opening: Mens sana in corpore sano}

The Roman saying mens sana in corpore sano points to a basic concept that in order to achieve a healthy spirit, a person needs a healthy body. A scholar on human learning, Peter Jarvis, notes: ' $\mathrm{t}$ ] he person is both body and mind, not just personality in the psychological sense' (2006, p. 48). The idea that individuals are constantly in the process of 'becoming' reflects the very notion of change and re-creation of the same yet transformed person as a whole. Unlike Kolb's learning cycle, in Jarvis' perception, learning entails a rather complex system and transformation resulting from learning includes a socially constructed experience, a reflection process, and both action and emotion. As the author would illustrate: the change of body, mind and self (Jarvis, 2006).

Change is a process that does not come easily to a school setting. For education systems around the world, enabling change and innovation comes with a bit or much difficulty because the system and the practices formulated around education are complex, rigid, and strongly traditional (Resnick, Goldman, Spillane, \& Rangel, 2010). Furthermore, the school-based practices are constructed in highly emotional relationships that are often overlooked when proposing change (James, 2010). The power of feelings plays a crucial role as learning is relational conduct between different school actors.

It seems essential in education to have a conscious and deep understanding of what works and why, as well as to reflect and critically develop those aspects that do not work. In order for teachers to feel well with their practice, they need a sense of routine (Hammerness et al., 2007; James, 2010) and one that has an impact and can make a difference, regardless whether it is related to the classroom approach, way of collaboration with others, relationship with the school leadership, or their interaction with students. Education is a conduit to the future through which society, and schools in particular, prepare generations for whatever is waiting. Thus, professionals in schools need to have a clear idea of their conduct and, more so, be able to transform the problematic frames of reference that are incoherent (Mezirow, 2009).

It is argued in this article that transformation does not come without a notion of change, nor does it come without challenges. More distinctively, transformative teacher learning does not happen alone, in isolation of change and challenges that occur in their professional environments. The purpose of this article is to find an answer to what constitutes transformative teacher learning in two schools that engage in student-centred reflective pedagogical practices and, as such, what are the changes and challenges that these schools face in supporting such transformations. The relevance of this work lies in the 
somewhat unknown notions of transformative teacher learning in schools that act as innovative learning environments and, more so, understanding the structural and human constructs that make transformative learning a reality.

\section{Theoretical considerations of the three-segment logic}

When placed in a particular order, change, challenge and transformation seem to imply a logical gradual thread. The section below attempts to justify the logic and presents how one notion creates a base for the other to be built on. In doing so, the article attempts to provide a basis for how the literature and the data are viewed, analysed, and discussed and to answer the questions of the dynamics of transformative teacher learning.

Much has been said about the need for a change in the way schools operate; Schleicher (2015) argues that it is of utmost importance to (re)build schools in order to become responsive to the needs of the $21^{\text {st }}$-century learners. This often includes changing the way school leadership is perceived, as well as working with teachers to become more confident in engaging in innovative work (Schleicher, 2015). School can also be seen as complex adaptive systems that need to manage the change mainly through altering two core behaviours connected to learning: the way continuous professional development is handled and the way teaching and learning is perceived (Horvath, Verderber, \& Barath, 2015). Echazarra et al. (2016) argue that schools have changed very little since they were first established and, as such, are failing to provide good preparation for the students facing current and future challenges. The 'four Cs' - creativity, critical thinking, communication, and collaboration -need to become integral to any curriculum and classroom practice; for this, several changes are needed within schools and education systems. For instance, the way students learn can no longer rely on memorisation alone; learning thus needs to become more versatile and independent (Echazarra et al., 2016).

Additional to this, school change is often closely connected to effective leadership approach which empowers the teachers and is focused on creating learning opportunities. Those schools that seem to perform better have a systematic approach to leadership, where the strategy is to distribute the power and create ownership among key stakeholders (Gregorzewski \& Kovacs, 2017; Hargreaves, Halász, \& Pont, 2007). The topic of effective leadership also connects to the understanding of school development (Day et al., 2009), and generates the basic idea that shared ideas of the needs, processes and outcomes should be owned by teachers and principals, but also educational policymakers and parents. 
In literature, school change has often been connected to a scope of a larger educational reform. Thus, Snyder et al. (1992) constructed three approaches that explain the processes of curriculum reform implementation and in what way it gets absorbed by the school. The three perspectives differ according to the initial engagement of stakeholders in the process of developing the curricular instruction, and more critically according to what is expected from teachers in their role as implementers of the curriculum. The role of teachers can go from being very passive to being an active agent of change as described in the curriculum enactment perspective. In the latter, teachers and students are considered to be active players and are invited to engage in curriculum design, as well as in the further co-creation of the curriculum through implementation in the classroom. The syllabus, accompanied by the formally devised materials, are used as tools for learning, free to be modified and adapted to the specific situations (Snyder et al., 1992).

Nonetheless, it is not all that simple and straightforward; James (2010) argues that by observing the educational change from the perspective of system psychodynamics, teaching involves a high level of affective intensity; thus, feelings hold a powerful influence over any change. Change can be energising and uplifting but also a cause for high anxiety and feeling of loss as it touches on routines and rituals that are logical for the school staff, therefore collective engagement over setting new ones holds great weight (James, 2010).

To change is to embrace the challenge that quite often is invisible and relational. In contrast, the visible part of it is often given in the form of an alternative methodology, a non-routine practice, or in other words, an educational innovation, most notably such that benefits the students. In a school setting, in most cases, this does not come with ease:

No-where is the challenge of innovation greater than in the education sector, where centuries-old practices of teaching are embedded in political and organisational structures which are resistant to new ideas - even in the face of growing evidence that traditional ways of working are not 'paying off'. (Resnick et al., 2010, p. 286)

In some of the literature, the resistance to change that is presented as the challenge to bringing innovation in schools is curable through systematic investment in developing a coherent school organisation and through a focus on school practice. Resnick et al. (2010) argue that developing learning communities helps not only to improve knowledge creation and management among the staff but is also useful for modifying teachers' practice.

The capacity for schools to be learning organisations (Senge, 1990) is an essential element in the puzzle. Senge notes that successful organisations are 
those that have the capacity as learning organisations, 'where people continually expand their capacity to create the results they truly desire, where new and expansive patterns of thinking are nurtured, where collective aspiration is set free, and where people are continually learning how to learn together' (Senge, 1990, p. 10). Put into perspective, learning in organisations implies individual learning and active engagement. While these are utmost necessary, they are not entirely sufficient in order to have a successful pattern of organisational learning (Ellström, 2001). It is the intricate web of coherent and complex relational, managerial, and organisational patterns that allow both professional and personal gains. In the teaching profession, satisfaction with professional growth and achievements plays a high role in performance and overall classroom success (Bakkenes, Vermunt, \& Wubbels, 2010; McCharen, Song, \& Martens, 2011; Timperley, Wilson, Barrar, \& Fung, 2007).

Following the conceptual ideas of the learning organisations, Giles and Hargreaves (2006) innovative schools have historically contained some (but not usually all agree that the idea could easily be applicable for schools that nurture the capacity for professional teacher learning, have a structural approach to innovation and can flexibly engage with solutions to emerging situations. The success of these knowledge-intensive school environments rests on the components such as collaborative work, consistent teaching, and learning strategies, and analysis of the results over time (Giles \& Hargreaves, 2006). Nevertheless, in the teaching profession, creating professional learning communities comes with its own set of challenges, one of which is the phenomenon of 'closed classroom doors', when teaching is considered to be private conduct. Other such challenges can be seen as high turnover or low retention in the teaching profession, as well as the lack of time and financial resources (Talbert, 2010).

It is argued here that transformative learning comes with a very distinct flavour and it is greater than mere informational learning that focuses on developing skills and knowledge. Kegan (2009) notes that the over-use of any term, including 'transformation' in learning, carries a risk of losing its essential meaning. In such a way, 'transformation begins to refer to any kind of change or process at all' (Kegan, 2009, p. 41). With the aim of preventing this from happening, the author argues it is crucial to understand and define the form that transforms because without the form there cannot be a transformation.

Jack Mezirow who coined the term, defined transformative learning as: 'the process by which we transform problematic frames of reference (mindsets, habits of mind, meaning perspectives) - sets of assumption and expectation to make them more inclusive, discriminating, open, reflective and emotionally able to change' (2009, p. 92). 
Change and challenge are crucial for this process as defined here. The mere realisation of change in terms of identifying the problematic frame of reference, as well as working along challenges to arrive at the point where reformulation is possible, is of great significance. In such a way, we can talk about transformative learning as 'an adult dimension of reason assessment involving the validation and reformulation of meaning structures' (Mezirow, 2009, p. 93).

While it is elemental to increase the scope of knowledge and the spectrum of skills, build upon the established cognitive structures and expand the corpus of resources, Kegan reminds us that all such learning is literally in-form-ative because it seeks to bring valuable new contents into the existing form of our way of thinking. [...] Trans-form-ative learning puts the form itself at risk of change' (2009, p. 42). The existing form, or in Mezirow's terminology the frame of reference, is challenged and modelled in a manner different from what it was.

From this perspective, Jarvis $(2006,2009)$ argues that transformative learning is a moment in which there is an interaction between a person and the experience. A person comes as a whole (body, mind, self) in a life history and the experience is a socially constructed episode in this life history. Learning that holds a transformative potential touches the person's emotions, enables thought and reflection, and causes internal action. In such a way, the individual is changed as a whole, body, mind and the self (Jarvis, 2009).

If applied to teacher professional development, transformative learning needs to be seen beyond mere work-based learning, encompassing the dimension of expansive learning (Engeström, 1987), integrating the knowledge of practice (Cochran-Smith \& Lytle, 1999) and providing a sense of empowerment and emotional satisfaction. While professional learning is already difficult to precisely define due to its highly tacit and implicit character, it is important to consider that transformative professional learning as both a process and an outcome might be even more demanding.

That said, the article further investigates teacher learning in schools that openly and intensely embrace change, thus questioning what characteristics of school staff's conduct encompass the notions of transformative learning.

\section{Method}

The idea of change is unavoidable and distinctly present in schools that cope with the challenges our societies face today. Therefore, the selection of the schools for data collection for the purpose of this paper has been focused on those that positively embrace change, observing it as an opportunity. Working within the scope of a larger research project entitled Teacher learning in 
innovative learning environments, in the context of educational reforms and developmental interventions has enabled this short study to get direct access to a corpus of qualitative data. The countries, Hungary and Portugal, were predetermined by the aforementioned research that is part of the European Doctorate in Teacher Education (Cervinkova \& Kalman, 2016).

A qualitative research approach has been used in both cases. The collection of data happened between October 2017 and April 2018. The qualitative inquiry included semi-structured interviews and small focus groups, and the data was analysed manually. For this paper, input from principals and from four teachers in both cases has been used in the analysis. In the case of Portugal, there were five interviews that were not voice-recorded due to the country's ethical code of conduct; therefore, the notes from the interviews and the interviewees quotations were analysed following the pattern of the three conceptual notions of this article: change, challenge, and transformation. In the case of Hungary, there were five respondents, two were interviewed individually (the principal and one teacher), and three were interviewed using a format of a small focus group. The responses were audio-recorded and transcribed, after which they were initially coded and further analysed using the same three-level pattern as in the Portuguese case. Even though the fact that national context matters significantly in discussions of how schools function, the unit of analysis for this paper is the school within which the transformative learning happens. Once coded, the schools were analysed with the help of the theoretical concepts described in the previous chapter.

From the perspective of contextual understanding, these two particular schools are set in complex and to some extent contradictory national settings. In the case of Portugal, school-based experimentation was introduced in the middle of the last century as exceptions to the rule that do not impede the routines (Roldão, 2003). Next to this, focusing more on the universal right to education and bringing real equal opportunity for all students were identified as two of the core principles the country should follow at the turn of the century (Amaro, 2000). In the past, changes at the system level in Portugal did not always persist at the school level, and learning from such challenges did support development of the latest educational provisions encouraging schools to take greater autonomy (Kovacs \& Tinoca, 2017).

In Hungary, the political and social transformation at the end of the 1980 s and even more at the beginning of the 1990s provided an impetus for educational change, providing freedoms for funding schools and acting against discrimination (Ministry of Education and Culture, 2008). Similar to the Portuguese reality, experimentation was not uncommon in Hungary, yet it did not entirely transform the educational system. At the turn of the century, the 
investment and provisions shifted to specifically targeted programmes and strictly regulated provisions primarily led by the state through European Social Funds (Halász, 2015).

The condensed outline of the national educational perspectives serves to indicate that both countries fluctuated with their tactics towards schooling and teachers' work, which nevertheless is necessary for understanding the setting. It is also vital to know that the two schools selected for this study slightly differ from the traditional provisions and seem to create an extra layer that needs elaboration. They both use a mix of inclusive and collaborative educational methods to address what they identify as educational goals. The initial selection of the schools, including the two in this study, followed expert advice within the two respective countries. The selection of the schools for the study can also be seen as a limitation of the study as they are not representative of the two countries; they thus provide insight only into their own practices. The particular selection of the two schools for this article was made based on the size and common ideas and structures the schools follow, which restricts the study from making generalisations and broad conclusions.

\section{Part one: The change}

In the Portuguese case, it was with the change of the leadership that facilitated a small private school to transform itself into an exciting learning space where knowledge thrives amongst students, teachers, and other school staff. The principal that arrived about five years ago brought energy and inspiration, having extensive previous work experience within the country and abroad. In particular, her work quite frequently focused on teacher education and continuous development that included different teaching and learning methods.

It is not a secret that some techniques and methodologies in teaching and learning help in changing the mind-sets and the attitudes of both teachers and learners. They, and especially the teachers, need to become more reflective, to have a continuous process of reflection and to put in doubt whether their work is successful and why. (Principal, PT school)

The change from the traditional instruction to a more active and reflective one changed the way the teachers worked on their preparation and lesson delivery. The initial great deal of uncertainty in whether their work is effective required feedback and collaboration, thus collegiality soon became a support system. Furthermore, it brought acceptance to the notions of pair-teaching in which additional engagement became a satisfying professional activity. 
Comparatively, in Hungary, the change was integral to the school development in the first place. Close to three decades ago, a group of teaching professionals, including the current principal, decided to use the momentum of favourable educational policies and make a school that would be more studentoriented. At that time, Hungary had a liberal approach to education, allowing a vast number of experiments (Halász, 2003).

In the ' 8 os in Hungary, it was kind of a pedagogical revolution with a great opportunity to develop new methods and new kinds of schools. We knew we wanted to place the child in the centre of our work, so several of us like-minded pedagogues gathered and researched what would be the best approach to establishing a child-centred school. (Principal, HU school)

The non-traditional methods were novel to the country and understanding them required searching and reading about the examples, as well as visiting other schools and talking to other teachers. The aim was simple and clear for everyone - a child is the central concern - so in order to get there, they started mixing different approaches they found appropriate.

Similar to the Portuguese school, the perspectives of differentiated learning that the Hungarian school implements brought in a dimension of collaboration, pair-teaching, and working as a team. The classroom practice in all their subjects required a vast number of worksheets and individualised learning templates that have been merged into the school's own books.

\section{Part two: The challenge}

The school in the Hungarian case approached change at its very establishment; when the group of teachers got together to form a school, it was clear 'what kind of school and practice we wanted, and we knew exactly what we did not want' (Principal, HU school). The idea of the school's mission was to be completely child-centred, and even if at the time it was not clear what kind of pedagogical methods and approaches they would install in practice, they all agreed with certainty about the goal of their educational conduct. Thus, they have dedicated time to read, observe, visit alternative schools and discuss developing the complex classroom methodology that will allow their educational conviction to thrive. After 27 years of perfecting it, they are considered to be a successful school.

Nevertheless, this was and still is not challenge-free. New, fresh-fromtraining teachers, but also those that have years of experience, found that they 
needed to dedicate more time and attention at the beginning of their work in the school in order to familiarise themselves with the methods and the logic of the specific classroom practice. Teachers explained how it was when they first started:

At the beginning it was hard. The first three-four months, until you find your way and understand how it is all going, it is very difficult. (Teacher 1, HU school)

When we start here, we need to pass a type of a specific school training through which we are introduced with the methods. We are also assigned a teacher-mentor that works with us in the first period until we can gain self-confidence. (Teacher 3 , HU school)

The Hungarian school tackled the challenges by creating a sense of belonging, collaboration and ownership. All interviewed teachers mentioned that they had immense support from their colleagues and they never felt left alone to deal with the difficulties. Nevertheless, the school had situations in which the novice teachers could not adapt to this community-oriented working culture, as the teachers in the focus group mentioned:

We did have teachers coming here and wanting to do their job on their own, without really collaborating with the rest. This didn't really work for anyone, for them or for us. (Teacher 3 , HU school)

He [the non-collaborative teacher] was not happy, we were not happy. This attitude for collaboration is the only thing that is necessary here, everything else is learnable, like the methods and stuff. But, the personality and the openness to work together - it is really necessary here. (Teacher 4, HU school)

The notion of 'happiness', accompanied by the feeling of accomplishment, seemed to be a recurrent idea that supported teachers through the challenges and contributed to the transformative aspects of their work. This was also evident in the Portuguese school:

Working at this school is very gratifying, and frankly, I do not know if I would ever be fully fulfilled as a teacher at a conventional school. (Teacher 1, PT school)

The Portuguese school has created a very strong support community among the teachers, and all have mentioned the importance of working and 
learning together. They gather for a meeting every second week to discuss the challenges and the opportunities that await in the following period. Furthermore, they all dedicate extra time to design the complex classroom and curricular practice; thus, their workload usually is not the anticipated eight hours per day. Similar to the school in Hungary, their classroom practice consists of a mix of independent work, small-group/project work and a joint part. In addition to this, the school has started experimenting with an all-year story-telling curriculum that integrates different subjects into one learning unit and offers a more illustrative, imaginative, and inter-disciplinary way to learn. The challenge is that it takes at least three weeks of joint teacher work to map out and fully develop the programme.

In the attempt to create a school-wide learning organisation, the Portuguese school also had problems:

At the beginning, it was very difficult, and some teachers that were here for a very long time were not very receptive of the new methods. They would argue that they have been working the same way forever and it seemed to them as pointless to change. (Principal, PT school)

Collaborative work is very important in the success of our school. In order to have interdisciplinary projects, there must be a constant articulation between the specialists of the different areas. (Teacher 1, PT school)

Teamwork is like one of the biotic relationships. (Teacher 4, PT school)

It is very common to exchange ideas when we need one or another piece of advice. We feel that the collaboration between each other is for the greater good. (Teacher 3 , PT school)

Having a strong conviction that creating a community based on good relationships, trust and respect, will solve the challenge of the 'lone teacher', the Portuguese school principal developed a team and devised a school-wise programme that touches every single subject and puts teachers to work closer together. Eventually, as described above, this made some teachers leave the school, causing a 'small crisis' (Principal, PT school). It also created a sense that teamwork and collaborative attitudes are unavoidable, thus opening the door to a potential transformation. 


\section{Third part: The transformation}

In the Portuguese school, the change came with a handful of challenges. Nevertheless, it did open an array of possibilities, one of which was the development of a new pedagogical programme. In translation from Portuguese, the abbreviation of their pedagogical programme means 'to fly', and the conceptual idea behind this approach is indeed intended to enable children to fully spread their wings through learning. The programme is based on the idea of learning relationships, on autonomy and responsibility, as well as on the idea of opportunity. The programme transformed the teaching role from being a traditional transmitter of knowledge to connecting with students on a deeper level in different capacities according to the students' needs, including in the form of a personal tutor/mentor.

They are fundamental pillars. For instance, the personal relationship between the teacher and the student, the tutor and the student and between the adult and the student, they are all very important, as we discuss in our frequent meetings. You cannot reach a student for whom you mean nothing. The diverse connections we make with the children provide a source of safety and trust. (Teacher 3 , PT school)

The change of teacher practice through transformative professional learning is quite often reflected in understanding the aspects of professionalism and responsibility in educating the whole child. Apart from expanding the teacher's professional capacity to the roles of tutors, curriculum planning in the Portuguese school also took a turn at which subjects are thought in an interdisciplinary way, as noted here:

We dared to take another step forward, and this year in the $7^{\text {th }}$ grade we are developing an interdisciplinary project work with the participation of several disciplines simultaneously. It is called the 'landscapes project', and in practice, it means colleagues of geography, natural sciences and history need to come together for classes and for planning. (Teacher 3 , PT school)

Next to this, as noted in the principal's viewpoint regarding the necessity for continuous reflection, the teachers seem to indeed continuously expand and work on themselves as professionals:

The practices at the school led to profound changes in the way I work. The reflective process we develop for students is also put into practice for the daily work of teachers. We are invited, on a regular basis, to 
question, reflect and debate our practices, which leads to new strategies, solutions, creativity and overall the capability to doing even better work. (Teacher 1, PT school)

Teachers see their transformation in the way and to the extent that they see their students developing. All of them expressed that the importance of their development is tied to better serving students, yet the emotional satisfaction and encouragement were evident as well:

There is a part of me that thinks we can be making way for future paradigms to change in other schools and dare to educate in the true meaning of the word. We can be writing history! - that's what I sometimes think. (Teacher 3, PT school)

Likewise, interviews in the Hungarian school provided evidence of a large emotional effect that the outcomes of transformative professional learning have on teachers.

It satisfies me to see that the children are happy, when they say they don't want to go for holidays because they want to stay longer in the school. It makes me feel I have done something good. (Teacher 3, HU school)

We really love the work here, and it is not difficult to do anything. (Teacher 4, HU school)

For the Hungarian school, placing the child in the centre of pedagogical and personal attention is paramount. The school welcomes children with different abilities and needs and is classified as an inclusive special education school. Using the differentiated approach, the school can address the needs of all its students, but the connection that teachers make by trying to personally know each child makes the level of respect and commitment even higher. This transcends into aspects of societal change:

We need to change the way society sees disability, and by starting here in the school, we talk a lot about these topics in order to raise sensibility. It is a complete change of viewpoint for everyone to understand different abilities, rather than to feel sorry for a certain disability regardless of which it is. (Teacher 2, HU school)

We do want to do the job well, but also everyone here feels they also own this school. If you think that this is yours, you are responsible for it and you will do everything best you can. (Teacher 4, HU school) 
Enabling a critical and reflective approach to the social norms and creating a sense of ownership for processes, content, and relationship that goes along with the commitment to the purpose of education was indeed the intention of the Hungarian school principal, who also engages in teaching in the school. She noted that the true sense of ownership brings the teachers closer to each other and to the school, and they are happier to engage in the learning process by and for themselves. From the perspective of both the principal and its teachers the school is in the process of constant and never-ending change, and while the aims towards the child-centred approach will always remain the same, the form in which this is achieved will consciously keep on transforming.

\section{Discussion: Teacher learning cannot be transformative alone}

The three-part story comes together here, as change, challenge and transformation become summarised through what was provided by the literature and the data. Transformation in terms of changing the form (Kegan, 2009), either in classroom practice, teacher learning or school organisation, does not come without the need for change. Actively understanding status-quo as ineffective fundamentally questions the form that needs to change. Furthermore, the initial change without a challenge might not bring a transformation.

Moreover, the challenge quite often is the change or stems from the elements of change (Resnick et al., 2010). Challenge within the change process inspires endurance with the idea and, once overcome, provides confirmation and expands the initial foundation (Kegan, 2009; Mezirow, 2009). Therefore, the initial form is debated, questioned, challenged, and changed with the meaning structures entirely reframed (Mezirow, 2009).

These concepts form an intricate web that contains great implications for transformative teacher learning. It confirms that transformative teacher learning cannot be considered as any type of learning, regardless of how informative or beneficial it might be for the teachers themselves. Furthermore, teacher learning is a type of strongly embedded work-place adult learning that involves great amounts of emotions; thus it is necessary to understand its essential place in the frame of the school, the local and spatial realities within which teachers work, and perhaps even wider in the frame of the education system. Only by comprehending this, is it possible to see the validity in the argument stated at the beginning, namely that teacher transformative learning cannot happen in isolation. There are at least two ways to argue this. 
Firstly, as noted just above, the transformation does not come without challenges and without realisation of the need to change. It was obvious from the data collected in the two schools, that change is necessary for accomplishing the missions set by those that implement education. This change was more intrinsic than caused by external factors, thus the 'original form' became questioned by the research participants. It could be easily argued that without identifying the need for change and without the determination to persist in it, the transformation could not be possible. The challenges came as noted by the participants, and again it was with the persistence in finding the solutions and keeping the focus on the change that the schools managed to maintain the transformation.

Moreover, in both cases, this was considered to be an ongoing process, which opens the possibility of a continuous changing of form, which is most likely to bring the teacher learning to a level of transformation. The transformation, often named as 'change of mindset', followed Ellström's idea (2001) that integration of relational features within a tight working community needs to go along with strategical leadership and enabling organisational patterns. In both the Hungarian and Portuguese schools, pair teaching that supported closer bonds between teachers was blended with a feeling of ownership and responsibility towards the educational processes and uplifted by the inspirational principal. The 'form that transforms' (Kegan, 2009) the conventional educational provision is the actual attempt to develop and merge classroom practice to those that suit the student population, their personalities and needs, as well as supporting the school's vision. Teachers are thus enabled to 'transform the problematic frames of reference' (Mezirow, 2009) and continuously (re)create their practices. Arguably the glue that sticks all this together is the feeling of accomplishment and joy; the Hungarian and Portuguese teachers feel that their efforts lead to 'something good' and potentially changing the ways of future societies. Hence, the importance of creating deeper relationships between everyone involved in teaching and learning in the school can be considered as an essential component for transformation.

Secondly, and largely based on what was previously stated, teacher learning cannot be transformative alone. As rooted in the workplace, the teacher environment has to be transformative as well. This is why the focus often is directed to creating learning organisations (Senge, 1990) and knowledge-intense innovative school environments (Giles \& Hargreaves, 2006). However, such attempts often contain little substance and provide no real effect and opportunity for teachers to truly enact change (Snyder et al., 1992). Furthermore, caution needs to be applied with one-size-fits-all solutions, as teacher learning is a 
highly tacit process that cannot be evaluated with standard measures, and requires personalised approaches that only learning-dedicated teams can achieve (Cochran-Smith \& Lytle, 1999). It can be argued that teacher transformative learning goes jointly with the level and quality of interaction between professionals, as well as the students and the community. The research participants have shared from their experiences that the practices in the schools, the community that they belong to, the possibilities they are encouraged to see and the distributed power and responsibility all support how they work (Schleicher, 2015) and how they feel about their teaching. The emotional part was again rather significant as it measures the commitment and the bravery to challenge the form by knowing that the outcome can only be beneficial for all, in whatever way it comes. This comes closely with the way leadership is dispositioned in the school and how the goals of education are perceived.

\section{Conclusion: The healthy mind and body}

Keeping one's body and mind healthy requires being aware of how they are interlinked. Mens sana in corpore sano might mean that one should not neglect the physical self while exercising the mind, but it also teaches that healthiness of the body is connected to how healthy our thinking is. Similar to the Romans, Jarvis (2009) seems to agree that when it comes to learning, and especially transformative learning, body, mind, and the self (identity) are not to be viewed separately. This can be analogously observed in teacher transformative learning; teachers that are in healthy professional environments operate with healthier minds, and vice versa - schools need teachers with exercised critical brains in order to have well-functioning school collectives. Therefore, examining the metaphor of body and mind, schools could be the body and the school staff can equate the mind. They are intertwined and cannot be 'healthy' separately. Transformation requires the healthy functioning; thus, the 'body' requires changing the organisational patterns in order to enable reflective practices to flourish, and the 'mind' needs to feel the purpose, the encouragement and satisfaction in order to keep the 'body' healthy. The identity or the school self is comprised of its community, and as such needs to be trained to be critical, enduring and empowered from changes and challenges that it faces. Thus, transformation encompasses the mind and the body and the identity of education as a whole; the challenge and the necessity for change stem from this.

Transformative learning touches the person's emotions, causing reflection and internal action (Jarvis, 2009) through which the problematic frames of reference are set into question and transformed to being more open, reflective, 
inclusive, discriminating and emotionally able to change (Mezirow, 2009). From this perspective, teacher learning is yet a piece of the puzzle that becomes transformative only by having the remaining of the system providing the potential for transformation.

\section{Acknowledgements}

As the author, researcher and a fellow educational colleague, I would like to express my gratitude and special thanks to the schools that have provided the data used in this article. I was humbled by the generosity, openness to discuss educational ideas, and the efforts to accommodate my request for data collection. Working with professionals from these two schools has enhanced the joy in my work and I am thankful for the knowledge I have gained from them.

The paper is part of the European Doctorate in Teacher Education (EDiTE) project that has received funding from the European Union's Horizon 2020 research and innovation programme under Marie Skłodowska-Curie grant agreement number 676452 .

\section{References}

Amaro, G. (2000). Curriculum innovation in Portugal: The Área Escola - an arena for cross-curricular activities and curriculum development. Geneva: International Bureau of Education UNESCO. Retrieved from http://www.ibe.unesco.org

Bakkenes, I., Vermunt, J. D., \& Wubbels, T. (2010). Teacher learning in the context of educational innovation: Learning activities and learning outcomes of experienced teachers. Learning and Instruction, 20(6), 533-548. doi:10.1016/j.learninstruc.2009.09.001

Cervinkova, H., \& Kalman, O. (2016). European doctorate in teacher education. Forum Oświatowe, 28(2), 10. Retrieved from http://www.edite.eu/

Cochran-Smith, M., \& Lytle, S. L. (1999). Relationships of knowledge and practice: Teacher learning in communities. Review of Research in Education, 24, 249-305. doi:10.2307/1167272

Day, C., Sammons, P., Hopkins, D., Harris, A., Leithwood, K., Gu, Q., ... Kington, A. (2009). The impact of school leadership on pupil outcomes final report. Nottingham: University of Nottingham. Retrieved from http://dera.ioe.ac.uk/11329/1/DCSF-RR108.pdf

Echazarra, A., Salinas, D., Méndez, I., Denis, V., \& Rech, G. (2016). How teachers teach and students learn: Successful strategies for school. OECD Education Working Papers No. 130. Paris: OECD Publishing. Retrieved from http://dx.doi.org/10.1787/5jm29kptoxxx-en

Ellström, P.-E. (2001). Integrating learning and work: Problems and prospects. Human Resource Development Quarterly Winter, 12(4), 421-435. Retrieved from https://www.mah.se/PageFiles/41319/ Ellström 2001.pdf 
Engeström, Y. (1987). Learning by expanding: an activity-theoretical approach to developmental research. Helsinki: Orienta-Konsultit. Retrieved from http://lchc.ucsd.edu/mca/Paper/Engestrom/ Learning-by-Expanding.pdf

Giles, C., \& Hargreaves, A. (2006). The sustainability of innovative schools as learning organizations and professional learning communities during standardized reform. Educational Administration Quarterly, 42(1), 124-156. doi:10.1177/0013161X05278189

Gregorzewski, M., \& Kovacs, H. (2017). A mix that works for school development: School leadership and knowledge shariNG. In L. Rasiński, T. Tóth, \& J. Wagner (Eds.), European perspectives in transformative education (pp. 204-215). Wroclaw: Wydawnictwo Naukowe Dolnośląskiej Szkoły Wyższej we Wrocławiu.

Halász, G. (2003). Educational change and social transition in Hungary. In E. Polyzoi, M. Fullan, \& J. P. Anchan (Eds.), Change forces in post-communist eastern Europe: Education in transition (pp. 55-73). London, UK, \& New York, NY: RoutledgeFalmer.

Halász, G. (2015). Education and social transformation in central and eastern Europe. European Journal of Education, 50(3), 350-371. doi:10.1111/ejed.12130

Hammerness, K., Darling-Hammond, L., Bransford, J., Berliner, D., Cochran-Smith, M., McDonald, M., \& Zeicher, K. (2007). How teachers learn and develop. In L. Darling-Hammond \& J. Bransford (Eds.), Preparing teachers for a changing world: What teachers should learn and be able to do (pp. 358-389). San Francisco, CA: Jossey-Bass. Retrieved from https://psugtep.pbworks.com/f/Preparing Teachers for a Changing World.pdf

Hargreaves, A., Halász, G., \& Pont, B. (2007). School leadership for systemic improvement in Finland: A case study report for the OECD activity Improving school leadership. Retrieved from https://www.oecd. org/edu/school/39928629.pdf

Horvath, L., Verderber, E., \& Barath, T. (2015). Managing the complex adaptive learning organization. Contemporary Educational Leadership, 2(3), 61-83. Retrieved from http://www.cel.journal.uj.edu. $\mathrm{pl} /$ documents/61921109/135013678/Horvath\% ${ }_{2} \mathrm{C}+$ Verderber\% $2 \mathrm{C}+\mathrm{Barath}+\% 28 \mathrm{nr}+3+\mathrm{w}+2015 \% 2 \mathrm{C}$ +s.+61-83\%29.pdf/62odd8bb-7418-479b-90a9-1e8cede8927b

James, C. (2010). The psychodynamics of educational change. In A. Hargreaves, A. Lieberman, M. Fullan, \& D. Hopkins (Eds.), Second international handbook of educational change (pp. 47-64). Dordrecht: Springer Netherlands.

Jarvis, P. (2006). Towards a comprehensive theory of human learning. Oxon, UK: Routledge.

Jarvis, P. (2009). Learning to be a person in the society: Learning to be me. In K. Illeris (Ed.), Contemporary theories of learning: Learning theoriests - In their own words. London, UK, \& New York, NY: Routledge Taylor and Francis Group.

Kegan, R. (2009). What 'form' transfroms? A constructive-developmental approach to transfomrative learning. In K. Illeris (Ed.), Contemporary theories of learning: Learning theoriests - In their own words (pp. 35-52). London, UK, \& New York, NY: Routledge Taylor and Francis Group.

Kovacs, H., \& Tinoca, L. (2017). Unfreeze the pedagogies: introduction of a new innovative measure in Portugal. Revista Tempos e Espaços Em Educação, 1o(23), 73-86.http://doi.org/10.20952/revtee.v10i23.7446 
McCharen, B., Song, J., \& Martens, J. (2011). School innovation: The mutual impacts of organizational learning and creativity. Educational Management Administration \& Leadership, 39(6), 676-694. doi:10.1177/1741143211416387

Mezirow, J. (2009). An overview on transformative learning. In K. Illeris (Ed.), Contemporary theories of learning: Learning theoriests - In their own words (pp. 90-105). London, UK, \& New York, NY: Routledge Taylor and Francis Group.

Ministry of Education and Culture. (2008). Education in Hungary past, present, future - an overview. Budapest: Department for EU Relations.

Resnick, L. B., Goldman, P., Spillane, J. P., \& Rangel, E. S. (2010). Implementing innovation: From visionary models to everyday practice. In H. Dumont, D. Istance, F. Benavides (Eds.), The Nature of learning: Using Research to Inspire Practice (pp. 285-315). Paris: OECD. doi:10.1787/978926408648714-en

Roldão, M. C. (2003). Strategies to promote good practice and innovation in schools - The Portuguese case. In OECD (Ed.), Networks of innovation: Towards new models for managing schools and systems (pp. 87-97). Paris: OECD Publishing.

Schleicher, A. (2015). Schools for 21st-century learners. Paris: OECD Publishing. doi:10.1787/9789264231191-en

Senge, P. M. (1990). The fifth discipline: The art and practice of the learning organization. New York, NY: Doubleday.

Snyder, J., Bolin, F., \& Zumwait, K. (1992). Curriculum implementation. In P. W. Jackson (Ed.), Handbook of research on curriculum (pp. 402-435). New York, NY: Macmillan Publishing Company. Talbert, J. E. (2010). Professional learning communities at the crossroads: How systems hinder or engender change. In A. Hargreaves, A. Lieberman, M. Fullan, \& D. Hopkins (Eds.), Second international handbook of educational change (pp. 555-571). Dordrecht: Springer Netherlands. doi: http://doi.org/10.1007/978-90-481-266o-6_32

Timperley, H., Wilson, A., Barrar, H., \& Fung, I. (2007). Teacher professional learning and development: Best evidence synthesis iteration. Iterative Best Evidence Synthesis Programme. Wellington: Ministry of Education. doi:10.1111/j.1744-7984.2007.00116.x

\section{Biographical note}

Helena Kovacs is an early-stage researcher with the European Doctorate in Teacher Education at Eötvös Loránd University in Budapest, Hungary. She holds a master's degree in Lifelong Learning: Policy and Management from Aarhus University, Denmark. Her current research focuses on teacher learning in innovative learning environments; her research interests also include educational policy, comparative education, and identity and education. 